\title{
Lower Of Cost Or Market Inventory Valuation: IFRS Versus US GAAP
}

Dahli Gray, Keiser University, USA

Clemense Ehoff Jr., Central Washington University, USA

\begin{abstract}
The lower of cost versus market (LCM) controversy regarding inventory cost measurement is presented. The differences between International Financial Reporting Standards (IFRS) and United States (US) Generally Accepted Accounting Principles (GAAP) are analytically compared. The link between US federal tax law and US GAAP is emphasized relative to a discussion of deferred taxes and potential US federal income tax revenue.
\end{abstract}

Keywords: Inventory; International Accounting; Generally Accepted Accounting Principles; Convergence

\section{INTRODUCTION}

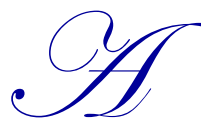

mong the more than 100 differences between United States (US) Generally Accepted Accounting Principles (GAAP) and International Financial Reporting Standards (IFRS), inventory valuation and impairment reversals get a considerable amount of attention. Disallowance of the last-in, first-out inventory (LIFO) method by the IFRS has been at the center of much discussion. Related to this has been the significant difference between IFRS versus US GAAP regarding the application of the lower of cost or market (LCM) measurement and reporting of inventory. This paper compares and contrasts the LCM valuation as required by IFRS versus US GAAP. This analysis will include some of the issues surrounding LIFO measurement and reporting differences between IFRS and US GAAP.

\section{INVENTORY VALUATION}

The basis of accounting for inventories is cost. This straightforward concept is frequently complicated by the entity's inability to match actual cost flow with specific physical units. US GAAP allows many ways (e.g., retail method) to measure the cost of inventory. The three basic and most popular methods are: 1) first-in, first-out (FIFO), 2) last-in, first-out (LIFO), and weighted average. Once the cost is measured, then the LCM rule is applied to the result to determine the monetary amount to be reported in the financial statements.

The LCM rule represents an application of the concept of conservatism which has been one of the dominant approaches used in forming and applying accounting rules under US GAAP. It is a practical attitude that attempts to avoid overstating assets and net income in the event of uncertainty. Conservatism is not an accounting principle, but the definition and application can be found in any accounting principles or intermediate accounting book (e.g., Wahlen, Jones, \& Pagach, 2013, pp. 2-21). Conservatism, as used by many practicing accountants, is to record anticipated losses now and defer gains until realized. A conservative approach was used in forming the LCM rule.

The application of LCM uses a conservative approach in an attempt to measure loss of value in the period in which it occurs. It compares inventory cost (i.e., value) as recorded on the financial books regardless of the method (e.g., LIFO, FIFO) used with market value. The term "market, for this purpose, is defined as current replacement cost not to exceed a ceiling of net realizable value (selling price less costs of completion and disposal) or be less than a floor of net realizable value less a normal profit margin" (Doupnik \& Perera, 2012). This computed market value is then compared to the inventory value recorded on the books. Inventory is written down to the lower of the two values (i.e., historical cost or market value). The adjusted value then becomes the new cost basis going forward under US GAAP. There is no provision for reversals. Any such recovery would be deferred until the 
inventory is sold or disposed of (AICPA, 2012, p. 149). The LCM acts as a conservatively approached "safety valve" by recording anticipated losses currently and deferring gains until realized.

IFRS inventory rules are less conservative than US GAAP inventory rules. Four significant differences separate US GAAP from IFRS. First, IFRS allows the use of the FIFO and weighted average methods, but LIFO is not permitted. Second, IFRS applies the lower of cost or net realizable value. Third, the historical inventory "cost" is used in applying the lower of cost or net realizable value over the entire period that the inventory is held. Fourth, write-downs are reversed as selling prices rise. Over the life of an entity, US GAAP and IFRS result in the same amount of expense (and profit) reaching the income statement. However, the inventory and cost of goods sold balances in any given period can differ dramatically. US GAAP standard setters have taken a similar conservative approach with respect to asset (e.g., Goodwill) impairment issues. Unlike IFRS, reversals of impairments are not permitted.

\section{LIFO IS A TAXING MATTER}

As mentioned above, IFRS inventory rules do not permit the use of LIFO. LIFO, as used in the US, is largely driven by a rather complex set of income tax rules as developed for the US and published as part of the US Internal Revenue Code. As of the year 2013, there is no international LIFO conformity rule (Whalen, Jones, \& Pagach, pp. 7-26).

Tax law in the US requires that LIFO be used for financial reports when it is used for tax reports. When the law was passed, there was significant inflation in the US. Inflation has been minimal during the $21^{\text {st }}$ century. Corporations subject to US tax law have voluntarily stopped using LIFO (Gray, 2013). This results in the possibility of US corporations using something other than LIFO for financial reporting and thereby also reporting in accordance with IFRS. The US law has not changed. However, the difference between IFRS and US GAAP has decreased in practice as US entities have decreased the use of LIFO for tax and financial reporting.

President Obama proposed that the inventory method of lower-of-cost-or market (LCM) be changed (DOT, 2012, p. 132). The changes would be effective for tax years beginning after December 31, 2013. To ease the cash flow from the taxed organizations to the federal government, the payments can be spread over 10 years (DOT, pp. 131-132). In essence, this component of the deferred tax process would be phased out over 10 years. This substantially expands the number of years currently specified in the Internal Revenue Code (IRC) section 481 (IRC, 2012).

The US Chamber of Commerce (2012) predicted that the "repeal of the lower-of-cost-or-market (LCM) and subnormal goods accounting methods [would] ... raise $\$ 8$ billion" in federal tax revenues." So, while the US federal government can see the potential revenue benefit, the corporate concern is that the potential cash outflow requirement for federal tax payable would increase. If LCM is changed, then retrospective application for financial reporting is required under the Financial Accounting Standards Board (FASB) accounting standards codification (ASC) 250-10-50.

If the US income tax law is changed so that inventory methods do not have to be the same in both income tax and financial statements, then converging IFRS and US GAAP would have one less hurdle and not be controversial. The change from one inventory method to another for financial statements could change reported net income without incurring a federal income tax cash flow impact.

\section{CONCLUSION}

Despite the many standard changes to fair value, LCM maintains a conservative approach. US GAAP follows a similar approach with respect to impairments by disallowing reversals.

Convergence of US GAAP toward IFRS will continue and, over time, differences between US GAAP and IFRS will likely diminish. However, US adaption is still far off. Other issues will likely keep the US from adopting IFRS completely (Ehoff \& Fischer, 2013). 


\section{AUTHOR INFORMATION}

Dr. Dahli Gray, CPA, CMA, CFE is an Accounting Professor at Keiser University. She earned her doctoral degree from the George Washington University. She has over 40 journal articles, including articles in journals such as the Journal of Accounting Research and the Journal of Accountancy. She has made over 60 professional presentations including at American Accounting Association meetings plus at other conferences in the United States and other countries such as Japan. E-mail: dahli.gray@waldenu.edu

Dr. Clemense Ehoff Jr., CPA, CGMA is an Assistant Accounting Professor, Central Washington University, Ellensburg, Washington. He holds a Ph. D in Business Administration from San Francisco's Golden Gate University. He has more than 30 years professional business experience and has held full-time faculty and adjunct positions at universities predominantly in the Eastern United States. Over the last ten years, Dr. Ehoff has been involved in teaching accounting and tax courses in an online platform as well as in the face-to-face classroom. He operates a consulting and tax practice. He has published articles in Elevator World and other journals. E-mail: drehoff@comcast.net (Corresponding author)

\section{REFERENCES}

1. American Institute of Certified Public Accountants (AICPA). (2012). Accounting trends \& techniques: U.S. GAAP financial statements best practices in presentation and disclosure $\left(64^{\text {th }}\right.$ ed.). AICPA.

2. Department of the Treasury (DOT). (2012, February). Repeal lower of cost of market (LCM) method of accounting for inventories. General explanations of the Administration's fiscal year 2013 revenue proposals. Retrieved from http://www.treasury.gov/resource-center/tax-policy/Documents/GeneralExplanations-FY2013.pdf\#page $=138$

3. Doupnik, T., \& Perera, H. (2012). International accounting ( $3^{\text {rd }}$ ed.). New York: McGraw-Hill Irwin.

4. Ehoff, C., \& Fischer, D. (2013). Why the SEC is delaying adoption of international financial reporting standards. International Business and Economics Research Journal, 12(2), 223-228.

5. Financial Accounting Standards Board (FASB). Accounting standards codification (ASC). 250 Accounting changes and error corrections-10 Overall-50 Disclosure (250-10-50). FASB.

6. Gray, D. (2013) IFRS and US GAAP convergence progressing: As taxpayers voluntarily stop using LIFO. International Business and Economics Journal, 12(4), 451-456.

7. Internal Revenue Code (IRC). (2012). Adjustments required by changes in method of accounting method. Cornell University Law School. Retrieved from http://www.law.cornell.edu/uscode/text/26/481

8. Pricewaterhouse Coopers (PwC). (2012, October). IFRS and US GAAP: Similarities and differences. PwC. Retrieved from http://www.pwc.com/en_US/us/issues/ifrs-reporting/publications/assets/ifrs-and-us-gaapsimilarities-and-differences-2012.pdf

9. United States (US) Chamber of Commerce (CoC). (2011, February 15). FY2012 Administration budget proposals. US CoC. Retrieved from http://waysandmeans.house.gov/uploadedfiles/us_chamber.pdf

10. US Department of Labor (DoL) Bureau of Labor Statistics (BLS). (2012, December 14). Consumer price index November 2012. Retrieved from http://www.bls.gov/news.release/pdf/cpi.pdf

11. Wahlen, J. M., Jones, Jefferson F., \& Pagach, D. P. (2013). Intermediate accounting: Reporting and analysis. Mason, $\mathrm{OH}$ : South-Western, Cengage Learning. 


\section{NOTES}

